\title{
HUBUNGAN FAKTOR LINGKUNGAN DENGAN KEJADIAN \\ ISPA PADA BALITA DI SUSUN LOR DESA RAMBI GUNDAM \\ KECAMATAN RAMBI PUJI KABUPATEN JEMBER
}

\author{
Oleh: \\ Eka Suryaning Tyas \\ STIKes Bhakti Al Qodiri Jember
}

\begin{abstract}
ABSTRAK
Lingkungan adalah kombinasi antra kondisi fisik yang mencakup keadaan sumber daya alam seperti tanah, air, energi surya, minerl serta flora dan fauna yang tumbuh di Atas tanah maupun lautan, dengan kelembapan yang meliputi ciptaan manusia di sebabkan oleh: (1) faktor demografi, (2) faktor biologis (3) faktor polusi (4) faktor timbulnya penyakit. Pada penelitian ini mempunyai tujuan mengetahui hubungan faktor Lingkungan dengan kejadian ISPA di dusun Lor desa Rambigundam .Penelitian ini merupakan desain korelasi, untuk menentukan sampel, menggunakan sampel random sejumlah 31 responden, alat pngukuran data mengunakan lembar observasi yang di lakukan pada tanggal 10 April Di dusun Kerajan Lor desa Rambigundam kecamatan Rambipuji Jember.

Pengolahan data meliputi: editing, coding, entry, scoring, trublating, kemudian data di analisa mengunakan wilcoxson. Hasil dari pengolahan data di peroleh sebagian besar responden mempunyai lingkungan yg cukup baik sebanyak 21 responden (68\%), dari Data riwayat ISPA sebagian besar responden pernah mengalami ISPA sebanyak 22 Responden (71\%), maka di peroleh hasil $\mathrm{p}$ value: $0,000 \mathrm{a}=0,05$ sehinga di simpulkan $\mathrm{H} 1$ di terima, artinya adalah hubungan faktor lingkungan dengan kejadian ISPA. Berdasarkan hasil penelitian di harapkan respon dapat menjaga kebersihan lingkungan, dengan cara menjaga kebersihan lingkungan maka responder akan terhindar Dari penularan ISPA.
\end{abstract}

Kata kunci: faktor lingkungan, ISPA

\section{ABSTRACK}

Evironment is a combination of physical conditions that include a state of natural Resources sush as soil, water, solar energiy, minerals, and flora and fauna that grow on theLand and in the oceans, whit institutions taht inclunde the creation of human-like decisions ofHow to use the physical environmoent, in toddlers ARI caused due to: (1) demographicFactor, (2) biological factor, (3) pullution factor, 4 factor of disease, in the parent work Ho the objective $t$ know the relation ship of environmental factor to the incidence of Respiratory infection in infants in hamlet kradjan rambigundam lor village. This research use analytic design correlation, to determine the sample using simpleRandom sampling a number of 31 respondents, tool measurement data using observation,sheets made on april 10 hamlet krajan rambigundam district of jember.

Data processing includes:editing,coding,entry,scoring,tabuling, and then analyzed the data using the wilcoxon.the result of processing the data acquired most of the respondents have 
a fairly good environment as much as 21 respondents(68\%), from the data history of respiratory infection most of the respodents had experienced respiratory infection by 22 respondents (71\%), the obtained result Pvalue :0,000@=0,05 therefore concluded that $\mathrm{H1}$ is accepted,it means there is a relationship of environmental factors to the incedence of ARI. Based on the result of the respondents expected to mantain the cleanliness of the environment, by making the environment then the respondent will avoid respiratory infections.

Keywords : Environment Factors, ISPA 


\section{Latar belakang}

Di Indonesia terjadi lima diantara 1000 bayi atau balita,Ispa mengakibatkan 150.000 bayi atau balita meninggal tiap tahun atau 12.500 korban perbulan atau 416 kasus perhari,atau 17 anak perjam atau 1 tiap menit (siswono,2007).

\section{Menurut(WHO)}

Kesehatan

Lingkungan(Environment Health) Suatu keseimbangan ekologi yang harus ada antara manusia dan lingkunganya agar dapat menjamin keadaaan sehat dari manusia .Ada beberapa macam lingkungan diantaranya lingkungan tidak sehat,faktor yang mempengaruhi lingkungan sehat dan tidak sehat diantaranya sumber air,pembuangan sampah,dan tempat BAB.Banyak masyarakat terutama balita yang rentan sekali terhadap penyakit menular maupun penyakit tidak menular seperti Diare,Demam berdarah dan ISPA.

ISPA atau infeksi Saluran Pernafasan Akut adalah penyakit infeksi akut yang menyerang salah satu bagian atau lebih dari saluran nafas mulai dari hidung hingga alveoli,termasuk jaringan adneksanya seperti sinus,rongga telinga tengah dan pleura.ISPA masih merupakan masalah kesehatan utama yang banyak ditemukan di Indonesia.

Gejala awal yang timbul biasanya berupa batuk pilek,yang kemudian diikuti dengan nafas cepat dan nafas sesak.Pada tingkat yang lebih berat terjadi kesukaran bernafas,tidak dapat minum,kejang,kesadaran menurun dan meninggal bila tidak segera diobati.Usia balita adalah kelompok yang paling rentan dengan infeksi saluran pernafasan.Kenyataannya bahwa angka morbiltas dan mobilitas akibat ISPA,masih tinggi pada balita di Negara berkembang.

Banyak faktor yang mempengaruhi kejadian penyakit ISPA,baik secara langsung maupun tidak langsung.Menurut Sutrisna(1993)faktor risiko yang menyebabkan ISPA pada balita adalah sosial ekonomi,status gizi,tingkat pengetahuan ibu dan faktor lingkungan,sedangkan menurut Depkes RI(2002),faktor penyebab ISPA adalah balita dengan berat badan lahir
rendah(BBLR),status gizi buruk,imunisasi tidak lengkap,kepadatan tempat tinggal dan lingkungan fisik.

Upaya penanganan ISPA dilakukan dengan cara menjaga kesehatan lingkungan dan menggunakan ventilasi rumah sebaik baiknya.bagi orang tua lebih memperhatikan keadaan balita dan menjaga sanitasi lingkungan sekitar rumahnya agar senantiasa bersih dan terhindar dari bakteri maupun virus .

Sehingga berdasarkan latar belakang diatas maka penullis akan melukukan penelitian tentang hubungan faktor lingkungan dengan kejadian ISPA pada balita di Dusun Krajan Lor desa Rambigundam Kecamatan Rambipuji Jember.

\section{METODOLOGI PENELITIAN.}

Pada bab ini peneliti menjelaskan tentang rancangan atau desain penelitian,kerangka kerja,populasi dan sample,variable penelitian,definisi operasional,tempat penelitian,waktu penelitian,instrumen/alat pengumpulan data,prosedur pengolahan data,pengolahan data analisa data,serta etika penelitian.

\section{Desain Penelitian}

Desain penelitian adalah sesuatu yang sangat penting dalam penelitian,memungkinkaan pengontrolan maksimal beberapa faktor yang dapat mempengaruhi akurasi suatu hasil(Nursalam,2008).Penelitian ini penggunakan rancangan penelitian korelasional yang mempelajari tentang Hubungan faktor lingkungan dengan kejadian ISPA.

\section{Hasil Penelitian}

\section{Data Umum}

\section{Gambaran Umum Tempat Penelitian}

Lokasi yang dijadikan tempat penelitian adalah Dusun Krajan Lor,Desa Rambigundam,luas wilayah Dusun Krajan Lor 8,5 Ha,terdiri dari 2 RT batas wilayah sebelah barat adalah persawahan,sebelah timur berbatasan dengan Sungai Dinoyo,sebelah utara berbatasan dengan 
Desa Gugut ,sebelah selatan berbatasan dengan Dusun Kraja Kidul.

\section{Data Identitas Responden Berdasarkan Umur}

Distribusi Frekuensi Responden Berdasarkan Umur balita di Dusun Krajan Lor Desa Rambigundam

\begin{tabular}{|c|c|c|c|}
\hline $\begin{array}{l}\mathbf{N} \\
\mathbf{0}\end{array}$ & $\begin{array}{l}\text { Umur(tahu } \\
\mathrm{n})\end{array}$ & $\begin{array}{l}\text { Frekuensi( } \\
\text { f) }\end{array}$ & $\begin{array}{l}\text { Prosentase( } \\
\%)\end{array}$ \\
\hline 1 & 1 & 3 & 10 \\
\hline 2 & 2 & 10 & 32 \\
\hline 3 & 3 & 10 & 32 \\
\hline 4 & 4 & 6 & 19 \\
\hline 5 & 5 & 2 & 7 \\
\hline & Jumlah & 31 & 100 \\
\hline
\end{tabular}

Berdasarkan data pada tabel di atas dapat diketahui bahwa responden yang berusia 2 dan 3 tahun di Dusun Krajan Lor Desa Rambgundam sebanyak 10 responden(32\%).

Data Identitas Responden Berdasarkan Jenis Kelamin

Distribusi Frekuensi Responden Berdasarkan Jenis Kelamin Balita di Dusun Krajan Lor Desa Rambigundam.

\begin{tabular}{|l|l|c|c|}
\hline $\begin{array}{l}\text { N } \\
\text { o }\end{array}$ & $\begin{array}{l}\text { Jenis } \\
\text { Kelamin }\end{array}$ & $\begin{array}{l}\text { Frekuensi } \\
\text { (f) }\end{array}$ & $\begin{array}{l}\text { Prosentase( } \\
\text { \%) }\end{array}$ \\
\hline 1 & $\begin{array}{l}\text { Laki- } \\
\text { Laki }\end{array}$ & 22 & 71 \\
2 & $\begin{array}{l}\text { Perempu } \\
\text { an }\end{array}$ & 9 & 29 \\
\hline \multicolumn{2}{|l}{$\begin{array}{l}\text { Jumlah } \\
\quad\end{array}$} & 31 & 100 \\
\hline
\end{tabular}

Berdasarkan data label di atas dapat diketahui bahwa responden yang berjenis kelamin laki laki di Dusun Krajan Lor Desa Rambigundam sebanyak 22 responden $(71 \%)$.

\section{Data Faktor Lingkungan}

Distribusi Frekuensi Responden Berdasarkan Faktor Lingkungan di Dusun Krajan Lor Desa Rambigundam.

\begin{tabular}{|c|c|c|c|}
\hline $\begin{array}{l}\mathbf{N} \\
\mathbf{0}\end{array}$ & $\begin{array}{l}\text { Faktor } \\
\text { Lingkung } \\
\text { an }\end{array}$ & $\begin{array}{l}\text { Frekuensi } \\
\text { (f) }\end{array}$ & $\begin{array}{l}\text { Prosentase ( } \\
\%)\end{array}$ \\
\hline 1 & Baik & 10 & 32 \\
\hline 2 & $\begin{array}{l}\text { Cukup } \\
\text { baik }\end{array}$ & 21 & 68 \\
\hline 3 & $\begin{array}{l}\text { Kurang } \\
\text { baik }\end{array}$ & $\mathbf{0}$ & $\mathbf{0}$ \\
\hline & Jumlah & 31 & 100 \\
\hline
\end{tabular}

Berdasarkan data pada tabel di atas dapat diketahui bahwa sebagian besar mempunyai Lingkungan yang cukup baik di Dusun Krajan Lor Dea Rambigundam sebanyak 21 responden $(68 \%)$.

\section{Data Khusus ISPA}

Distribusi Frekuensi Responden Berdasarkan Riwayat ISPA di Dusun Krajan Lor Desa Rambigundam.

\begin{tabular}{|l|l|c|c|}
\hline $\begin{array}{l}\text { N } \\
\text { o }\end{array}$ & $\begin{array}{l}\text { Riwayat } \\
\text { ISPA }\end{array}$ & $\begin{array}{l}\text { Frekuensi } \\
\text { (f) }\end{array}$ & $\begin{array}{l}\text { Prosentase( } \\
\% \text { ) }\end{array}$ \\
\hline $\mathbf{1}$ & $\begin{array}{l}\text { Mengala } \\
\text { mi }\end{array}$ & 22 & 71 \\
2 & $\begin{array}{l}\text { Tidak } \\
\text { Mengala } \\
\text { mi }\end{array}$ & 9 & 29 \\
\hline \multicolumn{2}{|l}{ Jumlah } & 31 & 100 \\
\hline
\end{tabular}

Berdasarkan data pada label di atas dapat diketahui bahwa sebagian besar responden yang mempunyai riwayat ISPA di Dusun Krajan Lor Desa Rambigundam sebanyak 22 responden $(71 \%)$ 
Hubungan Faktor Lingkungan Dengan Kejadian ISPA pada Balita di Dusun Krajan Lor Desa Rambigundam.

\begin{tabular}{|c|c|c|c|c|c|c|}
\hline \multirow{3}{*}{$\begin{array}{l}\text { Fakt } \\
\text { or } \\
\text { Ling } \\
\text { kung } \\
\text { an }\end{array}$} & \multicolumn{4}{|c|}{$\begin{array}{l}\text { ISP } \\
\text { A }\end{array}$} & \multirow{2}{*}{\multicolumn{2}{|c|}{$\begin{array}{l}\mathbf{J} \\
\mathbf{u} \\
\mathbf{m} \\
\mathbf{l} \\
\mathbf{a} \\
\mathbf{h}\end{array}$}} \\
\hline & \multicolumn{2}{|c|}{$\begin{array}{l}\text { Men } \\
\text { gala } \\
\text { mi }\end{array}$} & \multicolumn{2}{|c|}{$\begin{array}{l}\text { Tidak } \\
\text { Meng } \\
\text { alami }\end{array}$} & & \\
\hline & $\mathrm{f}$ & $\%$ & F & $\%$ & $\mathrm{f}$ & $\%$ \\
\hline $\begin{array}{l}\text { Kura } \\
\text { ng } \\
\text { baik }\end{array}$ & 0 & 0 & 0 & 0 & 0 & 0 \\
\hline $\begin{array}{l}\text { Cuku } \\
\text { p } \\
\text { baik }\end{array}$ & 14 & 67 & 7 & 33 & $\begin{array}{l}2 \\
1\end{array}$ & $\begin{array}{l}1 \\
0 \\
0\end{array}$ \\
\hline Baik & 8 & 80 & 2 & 20 & $\begin{array}{l}1 \\
0\end{array}$ & $\begin{array}{l}1 \\
0 \\
0\end{array}$ \\
\hline $\begin{array}{l}\text { Juml } \\
\text { ah }\end{array}$ & 22 & 71 & 9 & 29 & $\begin{array}{l}3 \\
1\end{array}$ & $\begin{array}{l}1 \\
0 \\
0\end{array}$ \\
\hline & $\begin{array}{c}P \\
\text { value } \\
=0,0 \\
00\end{array}$ & & & $\begin{array}{l}@= \\
0,0 \\
5\end{array}$ & & \\
\hline
\end{tabular}

Berdadarkan tabel pada di aatas bahwa responden yang mempunyai penilaian lingkungan cukup bak di Dusun Krajan Lor Desa Rambigundam sebanyak 21 responden sedangkan yang mengalami ISPA sebanyak 22 responden.

\section{Analisa Data}

Berdasarkan hasil uji analisa data dengan menggunakan uji unicoxon diperoleh hasil Pvalue $=0,000 @=0,05$ sehingga disimpulkan H1 diterima,artinya ada hubungan faktor lingkungan dengan keadian ISPA.

\section{Pembahasan}

Dapat diketahui bahwa sebagian responden memiliki lingkungan yang cukup baik di Desa Krajan Lor Desa Rambigundam sebanyak 21 responden(68\%).
Menurut (WHO,2005) Kesehatan Lingkungan meupakan suatu keseimbangan ekologi yang harus ada antara manusia dengan lingkungan agar dapat menjamin keadaan sehat dari manusia.Lingkungan hidup manusia dasarnya terdiri atas dua bagian,yaitu lingkungan hidup internal(berupa keadaan yang dinamis dan seimbang yang disebut homeostasis)dan lingkungan eskternal diluar tubuh manusia.lingkungan hidup eksternal terdiri dari atas tiga komponen,yaitu (Chandra,2005).(1)lingkungan fisik: lingkungan fisik bersifata biotic atau benda mati,sepertiair,udara,tanah,cuaca,makanan, rumah,panas,sinar,radiasi, dan lain lain.lingkungan fisik tersebut berinteraksi secara konstan dengan manusia sepanjang waktu dan memegang peran penting dalam proses terjadinya penyakit pada masyarakat,contohnya kekurangan persiadiaan air bersih,terutama pada musim kemarau,dapat menimbulkan penyakit di berbagai tempat. (2)lingkungan bologis:lingkungan biologis bersifat biotic atau benda hidup ,seperti:tumbuh tumbuhan ,hewan,virus,bakteri,jamur,parasit,serangga dan lain lain,yang dapat berfungsi sebagai agen penyakit,reservior infeksi,vektor penyakit atau hospes intermediate.hubungan manusia dengan lingkungan biologis bersifat dinamis dan pada keadaan tertentu,ketika terjadi ketidak seimbangan hubungan antara manusia dan lingkungan biologis,manusia akan menjadi sakit.(3)lingkungan sosial:lingkungan sosial dapat berupa kultur ,adat,kebiasaan,kepercayaan, agama,sikap,sta ndart gaya hidup,pekerjaan,kehidupan kemasyarakatan,serta organisasi sosial, dan politik.manusia dipengaruhi oleh lingkungan sosial melalu berbagai media,seperti radio,televisi,pers,seni,literature,cerita,lagu dan sebagainya.bila manusia tidak dapat menyesuaikan dirinya dengan lingkungan sosial akan tejadi konflik tujuan lainnya.berdasarkan kategori di atas,lingkungan hidup dapat diartikan sebagai kumpulan dari semua kondisi atau kekuatan dari luar yang mempengaruhi kehidupan dan perkembangan makhluk hidup termasuk manusia. 
Hal tersebut dikarenakan sebagian besar responden mempunyai kebiasaan yang tidak baik dalam menjaga dan memelihara kebersihan lingkungan rumah maupun di sekitar rumah dan keterbatasan pengetahuan dalam menjaga kebersihan lingkungan.

Berdasarkan tabel di atas dapat diketahui bahwa sebagian besar responden yang mengalami riwayat ISPA di Dususn Krajan Lor Desa Rambigundam sebanyak 22 responden(71\%).

ISPA adalah penyakit yang menyerang salah satu bagian atau lebih saluran nafas mulai hidung (saluran atas) hingga alveoli(saluran bawah)termasuk jaringan adneksanya,seperti sinus,rongga telinga dan pleura.ISPA umunya berlangsung selama 14 hari .yang termasuk dalam infeksi saluran nafas bagian atas adalah batuk pilek sinusitis.sedangkan infeksi yang menyerang bagian bawah saluran nafas seperti paru itu salah satunya adalah pneumonia.(WHO)ISPA (infeksi pernafasan akut)adalah infeksi akut saluran pernafasan bagian atas dan saluran pernafasan bagian bawah beserta adneksanya(Deskes RI,1993)ISPA adalah suatu penyakit yang terbanyak diderita oleh anak anak ,baik dinegara berkembang maupun di negara maju dan sudah mampu dan banyak dari mereka yang perlu masuk rumah sakit karena penyakitnya cukukp gawat.penyakit penyakit saluran pernafasan pada masa bayi dan anak anak dapat pula memberi kecacatan sampai pada masa dewasa(Suprajitno,2004)

Hal tersebut dikarenakan kurangnya manjaga kebersihan lingkungan sehingga sebagian besar responden benyak yang kurang memahami bahwa penularan ISPA di akibatkan oleh lingkungan yang tercemar serta masih banyak responden yang belum mengetahui apa itu ISPA ? dan bagaimana pengobatannya?.

\section{Hubungan Faktor Lingkungan Dengan Kejadian ISPA Pada Balita Di Dusun Krajan Lor Desa Rambi gundam}

Berdasarkan tabel di atas bahwa responden yang mempunyai penilaian lingkungan cukup baik di Dusun Krajan Lor Desa Rambi gundam sebanyak 21 responden sedangkan yang mengalami ISPA sebanyak 22 responden.Lingkungan adalah kombinasi antara kondisi fisik yang mencakup keadaan sumber daya alam seperti tanah,air,energi,surya,mineral,serta flora dan fauna yang tumbuh di atas tanah maupun di dalam lautan,dengan kelembagaan yang meliputi ciptaan manusia seperti keputusan bagaimana menggunakan lingkungan fisik tersebut.banyak faktor yang mempengaruhi kejadian penyakit ISPA ,baik secara langsung maupun tidak lansung .menurut Sutrisna(1993)faktor risiko yang menyebabkan ISPA pada balita adalah dari faktor lingkungan,sedangkan menurut Depkes RI ,2002,faktor penyebab ISPA adalah balita dengan berat badan lahir rendah(BBLR),status gizi buruk,imunisasi tidak lengkap,kepadatan tempat tinggal dan lingkungan fisik.

Faktor lingkungan sangat mempengaruhi kejadian ISPA pada balita,hal tersebut dikarenakan sebagian responden banyak yang tidak memperhatikan kebersihan lingkungan sekitar rumah maupun di dalam rumah sehingga dapat mempengaruhi kesehatan terutama pada balita yang akan mengakibatkan terjadinya ISPA.

\section{Kesimpulan}

Berdasarkan hasil penelitian dan pembahasan yang telah dilakukan maka dapat di simpukan bahwa factor lingkungan sangat berhubungan erat dengan kejadian ISPA sebagai berikut:

1. Faktor lingkungan di Dusun Krajan Lor Desa Rambigundam sebagian besar cukup baik sebanyak 21 responden(68\%)

2. Kejadian ISPA pada BALITA di di Dusun Krajan Lor Desa Rambigundam sebagian besar mengalami ISPA sebanyak 22 responden (71\%)

3. Ada hubungan factor lingkungan dengan kejadian ISPA di Dusun Krajan Lor Desa Rambigundam 


\section{DAFTAR PUSTAKA}

Ahmadi, UF. 2012. Manajemen penyakit berbasis wilayah, Jakarta : Rajawali Pres.

Arikunto, S, 2002. Prosedur Penelitian : Suatu Pendekatan Praktek, Jakarta : Raneka Cipt.

Arikunto, 2006. Prosedur Peneliaan Suatu Pendekatan Praktek, Jakarta: Salemba Medika.

Candra, Budiman, 2005. Pengantar Kesehatan Lingkungan, Jakarta : EGC.

Rahmawati, dwi dkk . 2012. ISPA Ganguan Pernafasan pada Anak Panduan Tenaga Kesehatan dan Umum, Yogyakarta ; Nuha Medika.

Departemen kesehatan RI, 1991. Pedoman Pemberantasan Penyakit Infeksi Saluran Pernafasan Akut Untuk Penaggulangan Pneumonia Pada Balita: Jakarta.

Departemen Kesehatan RI, 1991. Pedoman Kerja puskesmas, jilid 1, edisi 1991/1992, Jakarta.

Departemen kesehatan RI, 2005. Penanggulangan Pneumonia Balita

Depkes RI .2000, Pedoman Pemberantasn Penyakit ISPA.

Fathonah, S. 2005. Hygiene Dan Sanitasi Makanan. Semarang: Universitas Negeri Semarang Pres.

Mulia, R.M. 2005. Kesehatan lingkungan. Yogyakarta: Graha Ilmu.

Notoatmodjo, soekidjo, 2007. Kesehatan Masyakat Ilmu Dan Seni. Jakarta : PT. Renika Cipta, Jakarta.

Nursalam, 2011. Konsep dan Penerapan Metodologi Penerapan Ilmu Keperawatan Pedoman Skripsi, Tesis, dan Instrumen Penelitian Keperawatan. Jakarta : Salemba Medika.

Sugiono, 2011. Metode Penelitian Kuantitatif,Kualitatif Dan $R \& D$. Bandung : Alfabeta.
Slamet, JS. 2002. Kesehatan Lingkungan.

Yogyakarta : Gajah Mada University. 